\title{
蛋白漏出性胃腸症と汎血球減少症を合併した 脾臓原発組織球性肉腫の一例
}

\author{
牧島 秀樹, 北野 喜良 \\ 信州大学医学部第二内科

\begin{abstract}
Primary Splenic Histiocytic Sarcoma Complicated by Protein-losing
\end{abstract} \\ Gastroenteropathy and Pancytopenia
}

\begin{abstract}
A 68-year-old female was hospitalized because of general fatigue and edema. Physical examination revealed anemia and splenomegaly, and laboratory tests showed severe hypoproteinemia and pancytopenia. She was splenectomized and diagnosed as histiocytic sarcoma showing diffuse infiltration of large histiocytic cells $\left(\mathrm{LCA}^{-}, \mathrm{CD} 45 \mathrm{RO}^{-}, \mathrm{CD}^{-} 0^{-}\right.$, $\mathrm{CD}^{-} 5^{-}, \mathrm{CD} 30^{-}, \mathrm{CD}^{-}, \mathrm{CD}^{+} 8^{+} \mathrm{FDC}^{+}$, fascin $^{+}$). While any test including gastrointestinal endoscopy and bone marrow cytology did not detect infiltration of the sarcoma cells, hypoproteinemia and pancytopenia continued after splenectomy. An alpha anti-trypsin test revealed protein-losing gastroenteropathy. Despite of CHOP therapy-resistance, treatment with etoposide and prednisolone improved hypoproteinemia and pancytopenia.
\end{abstract}

Key words splenic tumor, histiocytic sarcoma, protein-losing gastroenteropathy, pancytopenia, etoposide.

はじめに

組織球性肉腫（Histiocytic sarcoma：HS）は比 較的まれな疾患であり ${ }^{1-5)}$. 非ホジキンリンパ腫 925 例のうち，4 例のみが HS と考えられたと報告され ている ${ }^{6)}$. 本疾患で増殖している腫瘍細胞は, B 細 胞， T 細胞の表面マーカーが陰性で組織球系の表 面マーカーが陽性である ${ }^{1,6-12)}$. 今までにいくつか の症例が報告されているが, 診断, 病態, 治療に関 し不明な点も多い ${ }^{2,3,6,7,12-21)}$. 今回われわれは, 脾 臓原発 HS に蛋白漏出性胃腸症と汎血球減少症を合 併した症例を経験したので報告し，過去の報告を検 討した。
症例

患者：69歳，女性

主訴：全身倦怠感，下腿浮腫

家族歷および既往歴：特記すべきことなし

現病歷：1996年 5 月全身倦急感と下腿浮腫を自覚し 当院受診。末梢血検查にて白血球 (WBC) 1900 / $\mu 1$ ，へモグロビン ( $\mathrm{Hb}) 6.2 \mathrm{~g} / \mathrm{dl}$, 血小板 (Plt) 1.8 万 $/ \mu 1$, 総蛋白 (TP) $3.4 \mathrm{~g} / \mathrm{dl}$, アルブミン (Alb) $2.1 \mathrm{~g} / \mathrm{dl}$ と汎血球減少と低蛋白血症を認め た。腹部 CT にて脾腫崵を認め（図 1 )，6 月に脾 蔵摘出術を施行された。摘出標本は $685 \mathrm{~g} て ゙$, 顕微 鏡的検索では，大型で異型性のある組織球様細胞の びまん性増殖を認め，領食能を有していた（図 2

A)。細胞質に Birbeck 顆粒を認めなかった．免疫 
染色の検討では，単球系のマーカー[PGM-1：モ， クローナル抗 CD68 抗体（図 2B）とライソザイム] は陽性, リンパ球系マーカー（LCA, CD45RO, $\mathrm{CD} 20, \mathrm{CD} 30, \mathrm{CD} 35)$ と好中球系マーカー （CD15）は陰性であった. ランゲルハンス細胞/樹 状細胞のマーカーの検討では, FDC と fascin は陽 性であった。以上から脾臓原発 HS と診断した。顕 微鏡的にリンパ節転移を認めなかった。脾臟摘出 後, 症状は一過性に改善したが, 1996年10月頃, 再 び増悪した（WBC $1200 / \mu 1, \mathrm{Hb} 6.8 \mathrm{~g} / \mathrm{dl}, \mathrm{Plt}$ $16,000 / \mu \mathrm{l}, \mathrm{TP} 2.7 \mathrm{~g} / \mathrm{dl}, \mathrm{Alb} 1.8 \mathrm{~g} / \mathrm{dl}$ ) (図 3 ). 腫瘍マーカーはフェリチン $2454.9 \mathrm{ng} / \mathrm{ml}$, 可溶性 IL-2 レセプター (sIL-2r) 1930U/ml とそれぞれ増 加し, 血清ビタミンは葉酸 $2.9 \mathrm{ng} / \mathrm{ml}$, ビタミン $\mathrm{B}_{12} 120 \mathrm{pg} / \mathrm{ml}$, ビタミン $\mathrm{B}_{6} 2.3 \mathrm{ng} / \mathrm{ml}$ と減少して

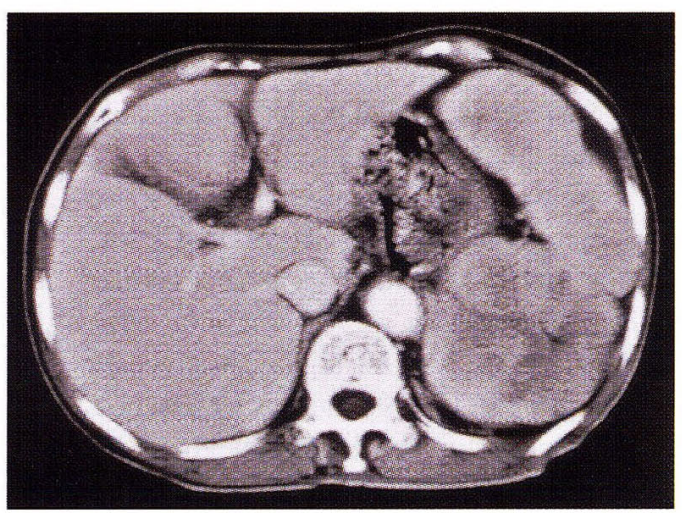

図 1 1996年の腹部 CT において, 脾臟に円形の占拠性 病変を認めた。

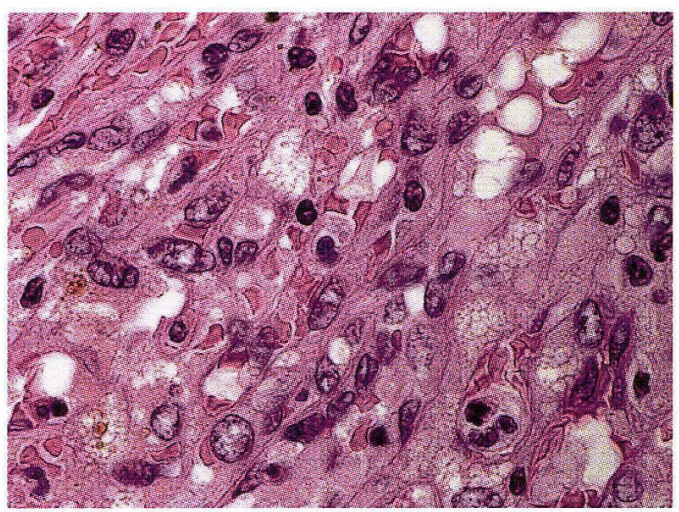

いた。尿蛋白を認めなかった。糖尿病を合併してい たが，インシュリンの皮下注射を施行されコント ロールは良好であった。リパーゼとキモトリプシン の血中濃度は正常範囲内にあり, 便中に脂肪滴を認 めなかった。食事は抢よそ1600kcalで，ほとんど 全量を摂取していた。栄養摂取と吸収能は正常範囲 内にあると考えられた。 $\alpha 1$ アンチトリプシンクリ アランス試験において陽性所見 $47 \mathrm{ml} / \mathrm{day}$ (正常範 囲は13未満）を認め，蛋白漏出性胃腸症と診断され た。上部，下部消化管内視鏡検査により異常を認め ず, 胃, 十二指腸, 結腸, 直腸の消化管粘膜に腫瘍 細胞の浸潤を認めなかった。 小腸二重造影では異常 な病変を指摘されなかった。 CT, MRI，ガリウム シンチグラフィーにて腫瘍細胞の浸潤を示唆する所 見を認めなかった。蛋白漏出シンチグラフィーを施 行したが，漏出部を特定を特定できなかった。骨䯣 検査では，正形成で赤芽球優位であり，軽度の巨赤 芽球性変化を認め, 骨髄系, 巨核球系においても軽 度の形態異常を認めた。腫瘍細胞の浸潤は認めな かった。負血に対しては赤血球輸血を必要とした。 組織学的には同定できなかったが，蛋白漏出性胃腸 症と汎血球減少の原因として HS の腸管と骨髄病変 を考え, プレドニゾロン (PSL) 40mgとエトポシド （VP16）50mgを投与した。 その後, 汎血球減少症と 低蛋白血症は徐々に改善し, 1997年 5 月に退院し た.しかし, 同年 9 月に再び増悪し (WBC 1200/ $\mu 1, \mathrm{Hb} 6.8 \mathrm{~g} / \mathrm{dl}$, Plt $16,000 / \mu \mathrm{l}$, TP $2.7 \mathrm{~g} / \mathrm{dl}$, $\mathrm{Alb} 1.6 \mathrm{~g} / \mathrm{dl}$ ), 再入院した. CHOP 療法を施行し たが奏効せず，PSL（30mg連日投与）とVP16（50

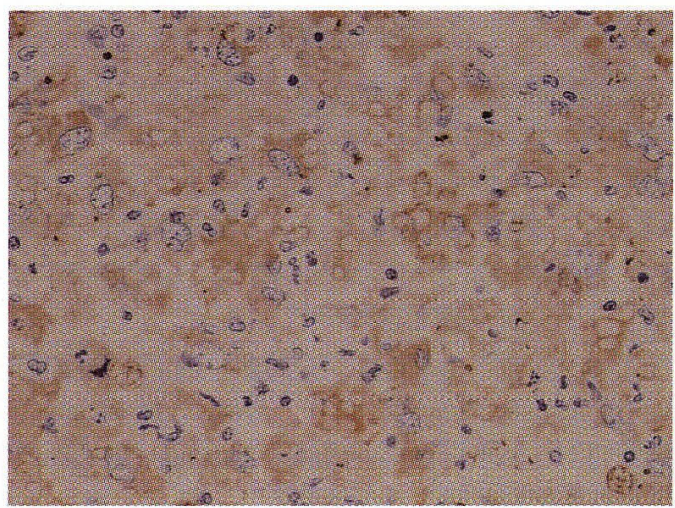

図 2 脾臓腫瘍のパラフィン切片標本.

A：へマトキシリンエオジン染色では大型の異型性のある組織球系細胞のびまん性の浸潤を認める (400倍). B : 腫晅細胞はモノクローナル抗 CD68 抗体に陽性である (100倍). 
mg 10日投与 18 日休薬）を再び経口投与した．汎血 球減少症と低蛋白血症は改善し，同治療の継続によ り 8 力月間増悪傾向を認めなかった. 1999年 1 月再 燃し, 再々入院した。この際サイトカインを測定し たところ，インターロイキン $3(\mathrm{IL}-3)<15 \mathrm{pg} / \mathrm{ml}$, 顆粒球コロニー刺激因子 (G-CSF) $1424 \mathrm{pg} / \mathrm{ml}$ $(<39)$, 顆粒球単球コロニ一刺激因子（GM $-\mathrm{CSF})<5.0 \mathrm{pg} / \mathrm{ml}$ であり, 補充している $\mathrm{G}-\mathrm{CSF}$ 以外は検出感度以下であった. CEPP 療法（シクロ ホスファミド (CPM), VP16, プロカルバジン, PSL）を施行したが改善せず，1999年 3 月に敗血症 とエンドドキシンショックにて死亡した。臨床経過 については図 3 に示す。

\section{考案}

HS は，樹状細胞と単球系細胞を含んだ組織球系 細胞由来の悪性腫瘍とされている. true histiocytic lymphomaとも称され, 比較的まれな疾患で, 病 態, 治療に関して依然不明な点が多い。本症例で認
められた腫瘍細胞は, 明るい大型の核を持ち, 細胞 質は広く, 貪食能を持ち, 表面形質では単球系とう ンゲルハンス細胞/樹状細胞系のマーカーが陽性で, リンパ球系と顆粒球系マーカーは陰性であった。 Kimura らが報告している脾臓原発 HS と同一の疾 患と考えられ, 同疾患と診断した. しかし, 現在で も組織球とされるものの系統的理解が必ずしも十分 とはいえないため, 本疾患の確定診断が困難となっ ている可能性があるように思われた。

文献検索した限りでは, 脾臓原発 HS は表 1 のご とく過去に 7 例の報告があるのみである ${ }^{7,10,14-17)}$. 男女比は $1: 1$ で, 年齢は 6 歳から66歳にわたり, 平均は41.6歳である. 3 例に低蛋白血症を認めた が，原因に関して診断している報告はなかった．血 球減少に関しては，1例に白血球減少を，3例に貧 血を，5例に血小板減少を認めた。 1 例では血球減 少を認めなかった。

本症例は， $\alpha 1$ アンチトリプシンクリアランス試 験にて蛋白漏出性胃腸症と診断したが, 我々が検索

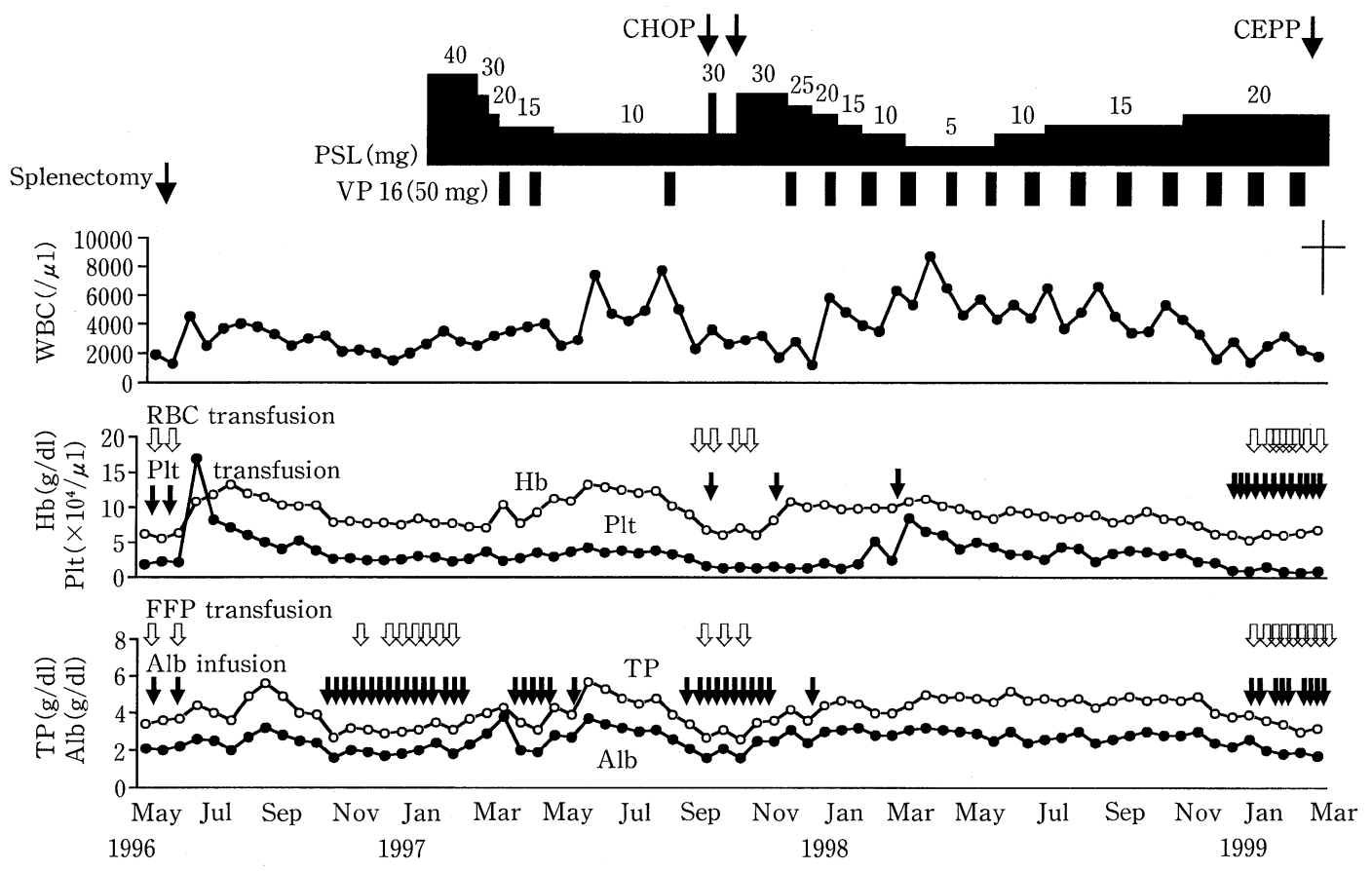

図 3 臨床経過

WBC, white blood cell ; Hb, hemoglobin; Plt, pletelet; TP, total protein ; Alb, albumin ; PSL, prednisolone ; VP16, etoposide ; FFP, fresh frozen plasma ; CHOP, cyclophosphamide adriamycin vincristine prednisolone ; CEPP, cyclophosphamide etoposide procarbazine prednisolone 
表 1 Clinical features, histopathology and immunophenotypes in patients with primary splenic histiocytic sarcoma

\begin{tabular}{|c|c|c|c|c|c|c|c|c|c|c|c|}
\hline \multirow{2}{*}{ No. } & \multirow{2}{*}{ Sex/Age } & \multirow{2}{*}{ Hypoproteinemia } & \multirow{2}{*}{ Cytopenia } & \multicolumn{6}{|c|}{ Characteristics of tumor cells } & \multirow{2}{*}{ Outcome* } & \multirow{2}{*}{ Reference } \\
\hline & & & & Phagocytosis & Birbeck granules & $\mathrm{L} 26$ & UCHL1 & CD68 & S100 & & \\
\hline 1 & $\mathrm{~m} / 29$ & + & $\mathrm{T}$ & + & - & - & - & + & \pm & 61 , died & {$[7]$} \\
\hline 2 & $\mathrm{~m} / 60$ & + & $\mathrm{T}$ & + & - & - & - & \pm & + & 18, died & {$[7]$} \\
\hline 3 & $\mathrm{f} / 66$ & + & $\mathrm{A}, \mathrm{T}$ & + & - & - & - & + & \pm & 30, died & {$[7]$} \\
\hline 4 & unknown & - & - & + & - & - & ND & + & ND & unknown & [14] \\
\hline 5 & $\mathrm{~m} / 38$ & - & $\mathrm{T}$ & + & - & - & - & $\mathrm{ND}$ & - & 21 , alive & {$[15]$} \\
\hline 6 & $\mathrm{f} / 51$ & - & A & + & - & $\mathrm{ND}$ & $\mathrm{ND}$ & $\mathrm{ND}$ & ND & 7 , alive & {$[16]$} \\
\hline 7 & $\mathrm{f} / 6$ & unknown & $\mathrm{L}, \mathrm{A}, \mathrm{T}$ & + & - & ND & ND & ND & ND & 39 , died & {$[17]$} \\
\hline 8 & $\mathrm{f} / 69$ & + & $\mathrm{L}, \mathrm{A}, \mathrm{T}$ & + & - & - & - & + & \pm & 33 , died & this case \\
\hline
\end{tabular}

Abbreviations : T, thrombocytopenia ; A, anemia ; L, leukopenia ; ND, not done ;*, months from the onset

し得た限りでは，今までに低蛋白血症の原因を説明 した報告はなく，脾臓原発 HS に合併する低蛋白血 症の病態を明らかにした初めての症例である。しか し, 本症例でも各種内視鏡検査, 画像検査にても蛋 白漏出部位は断定できず，小腸を除く部位での生検 による組織学的検討でも異常組織球の粘膜浸潤は証 明できなかった。脾臓以外の HS では消化管の生検 および切除標本が検討されており，回腸粘膜への高 頻度の浸潤が報告されている年,18). しかし, HS由 来の腫瘍細胞が小腸粘膜へ浸潤しやすい性格を持つ かどうかは不明であり，そのメカニズムを説明した 報告はなく，今後の検討が待たれる.

本症例における沈血球減少症は, 造血に関与する サイトカイン (IL-3, G-CSF, GM-CSF) やビタ ミン (葉酸, ビタミン $\mathrm{B}_{12}$, ビタミン $\mathrm{B}_{6}$ ) の不足 が原因の 1 つとして疑われた. しかし, G-CSF と ビタミンの静脈内補充療法により，著明な改善を認 めなかった。ただ, 補充しなかった IL-3, GMCSF は著明に低下しており, 蛋白漏出性胃腸症に 続発した造血因子欠乏は検索したもの以外にも及 び, 汎血球減少症を引き起こした可能性も考えられ た。なお，過去の症例において，サイトカインを測 定した報告を認めなかった。 さらに, フェリチンや sIL-2r の高值などからは, 腫瘍細胞の骨髄浸潤に よる血球貪食によるものが疑われた，骨髄検査は初 診時を含め 5 回施行したが組織球系細胞の増殖は認 められなかった。ただ，もし腫瘍細胞が骨髄内で局 所的に増殖していた場合は, 穿刺吸引および生検に
て腫瘍部分を採取できなかった可能性もあり, 原疾 患の腫瘍浸潤や，血球貪食症候群は完全には否定で きないと思われる。

本症例では低蛋白血症と汎血球減少症に対し CHOP 療法は不応であったが, VP16と PSLの併 用療法は有効であった。過去の報告によれば，HS の患者に対する多剤併用化学療法として CHOP 療 法 $^{3)}, \mathrm{MECP}$ 療法（ミトキサントロン, VP16, カ ルボプラチン, $\mathrm{PSL})^{7)}$, BACOP療法 (ブレオマ

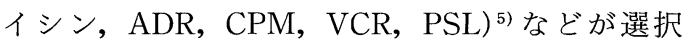
されている.症例によっては放射線療法が選択され た報告もある ${ }^{1,4)}$. 脾臓原発症例のうち数例は, 脾 摘後に汎血球減少症と低蛋白血症が一過性に改善し たことが報告されており ${ }^{7,14,15,17)}$, 本症例でも脾摘 後に検査値の改善を認めた。

皮膚原発の $\mathrm{HS}^{6)}$ は，一般的には進行性で長期生 存症例は少ないと報告されている。一方, 脾藏に病 変が限局している HS では, 表 1 のごとく, 進行は 比較的緩徐で長期生存を保っていた。

今回, 脾臓原発 HSで, 特異な合併症を来たし, VP16と PSLの併用が有効であった症例を報告し た. 本疾患に関して今後の検討が期待される。

謝辞：本症例の診断に際しまして, 中村栄男先生 （愛知県がんセンター病院・臨床検査部）に は大変にお世話になりました。, 心から感謝致 します。

\section{文 献}

1) Milchgrub S, Kamel WO, Wiley E, Vuich F, Cleary LM, Warnke AR : Malignant histiocytic neoplasms of the small intestine. Am J Surg Pathol 16 : 11-20 1992 
2 ) Kamel WO, Gocke DC, Kell LD, Cleary LM, Warnke AR: True histiocytic lymphoma : a study of 12 cases based on current definition. Leuk Lymphoma 18 : 81-86 1995

3 ) Mirchandani I, Shah I, Palutke M, Varadachari C, Tabaczka P, Franklin R, Bishop C: True histiocytic lymphoma. A report of four cases. Cancer 52:1911-1918 1983

4 ) Miettinen M, Fletcher CDM, Lasota J : True histiocytic lymphoma of small intestine. Analysis of two S-100 protein-positive cases with features of interdigitating reticulum cell sarcoma. Am J Clin Pathol 100 : 285-292 1993

5 ) Thomas P, Said JW, Rosenfelt FP, Heifetz LJ : True histiocytic lymphoma : an immunohistochemical, ultrastructural study of two cases. Am J Clin Pathol 81 : 243-248 1984

6 ) Ralfkiaer E, Delsol G, O'connor TJN, Brandtzaeg P, Brousset P, Vejlsgaard GL, Manson DY : Malignant lymphomas of true histiocytic origin. A clinical, histological, immunophenotypic and genotypic study. J Pathol $160: 9-171990$

7 ) Kimura H, Nasu K, Sakai C, Shiga Y, Miyamoto E, Shintaku M, Wakatsuki S, Tominaga K, Abe M, Maruyama Y : Histiocytic sarcoma of the spleen associated with hypoalbuminemia, hypo gamma-globulinemia and thrombocytopenia as a possibly unique clinical entity report of three cases. Leuk Lymphoma 31 : 217-224 1997

8 ) Darrell CJ, Kenneth AF : Recent advances in flow cytometry : application to the diagnosis of hematologic malignancy. Blood $90: 2863-28921997$

9) Cline JM : Histiocytes and histiocytosis. Blood 84 : 2840-2853 1994

10) Lauritzen FA, Ralfkiaer E : Histiocytic sarcomas. Leuk Lymphoma 18 : 73-80 1995

11) Furukawa F, Taniguchi S, Oguchi M, Komura J, Takiuchi H, Shirakawa S : True histiocytic lymphoma. Arch Dermatol 116 : 915-918 1980

12) van der Valk P, van Oostveen JW, Stel V, van der Kwast TH, Melief CJM, Meijer CJLM : Phenotypic and genotypic analysis of large-cell lymphomas, formerly classified as true histiocytic lymphoma : identification of an unusual group of tumors. Leuk Res 14 : 337-346 1990

13) Soslow RA, Davis RE, Warnke RA, Cleary ML, Kamel OW : True histiocytic lymphoma following therapy for lymphoblastic neoplasms. Blood 87 : 5207-5212 1996

14) Hanson CA, Jaszcz W, Kersey JH, Astorga MG, Peterson BA, Gaj1-Peczalska KJ, Frizzera G : True histiocytic lymphoma : histopathologic, immunophenotypic and genotypic analysis. Br J Haematol 73 : 187-198 1989

15) Franchino C, Reich C, Distenfeld A, Ubriaco A, Knowles MD : A clinicopathologically distinctive primary splenic histiocytic neoplasm. Demonstration of its histiocytic derivation by immunophenotypic and molecular genetic analysis. Am J Surg Pathol 12 : 398-404 1988

16) Govoni E, Bazzocchi F, Pileri S, Martinelli G : Primary malignant fibrous histiocytoma of the spleen : an ultrastractural study. Histopathology 6 : 351-361 1982

17) Johnson DE, Greip JA, Baehner RL : Histiocytic leukemia following lifelong infection and thrombocytopenia : histologic, metabolic, and bactericidal studies. J Pediatr 82 : 664-671 1973

18) Cline MJ, Golde DW : A review and reevaluation of the histiocytic disorders. Am J Med 55 : 49-60 1973

19) Elghetany MT : True histiocytic lymphoma : is it an entity? Leukemia $11: 762-7641997$

20) Esteve J, Rozman M, Campo E, Munoz F, Urbano-Ispizuna A, Rozman C : Leukemia after true histiocytic lymphoma : another type of acute monocytic leukemia with histiocytic differentiation (AML-M5c). Leukemia $9: 1389-13911995$

21) van der Valk P, te Velde J, Jansen J, Ruiter DJ, Spaander PJ, Cornelisse CJ, Meijer CJLM : Malignant lymphoma of true histiocytic origin : histiocytic sarcoma. Virchows Arch 391 : 2492651981 
22) Hsu SM, Ho YS, Hsu PL : Lymphomas of true histiocytic origin. Expression of different phenotypes in so-called true histiocytic lymphoma and malignant histiocytosis. Am J Pathol $138: 1389-14041991$

23) Lanzkowsky P : Manual of Pediatric Hematology and Oncology. 2nd ed. Churchill Livingstone New York pp493-511 1995

24) Hsu S, Hsu P : Phenotypes and phorbol ester-induced differentiation of human histiocytic lymphoma cell lines (U-937 and SU-DHL-1) and Reed-Sternberg cells. Am J Pathol 122 : 2232301986 